\title{
Dynasty Control of the Process of Forming a Coalition of Political Parties in the 2020 Cilegon Local Leaders Election
}

\author{
Abdul Riyansah \\ Government Department, Sultan Ageng Tirtayasa \\ University \\ abdulriyansah11@gmail.com

\section{Ferliana} \\ Government Department, Sultan Ageng Tirtayasa \\ University \\ ferliana2500@gmail.com \\ Yeby Ma'asan Mayrudin \\ Government Department, Sultan Ageng Tirtayasa \\ University \\ yeby@untirta.ac.id

\section{Moh. Rizky Godjali} \\ Government Department, Sultan Ageng Tirtayasa \\ University \\ rizky.godjali@untirta.ac.id
}

\section{E-ISSN 2721-0642}

Article Info

Recieved:

September 72021

Revised:

November 152021

Accepted:

December 162021

Doi Number

https://doi.org/10.37950/ijd.v3i3.114

\begin{abstract}
This paper discusses the power of political dynasties in Cilegon in the process of forming a coalition of political parties in the 2020 Pilkada. The embodiment of political dynasties continues to be accommodated to perpetuate power by putting aside the track record of organizing experience both in parties and in state institutions. The theory used in this study is the theory of political dynasties and party coalitions. The research method uses a qualitative study with an explanatory case study approach. The focus of this study is to explain how coalition maps are formed and how the influence of dynasties on political parties. The results of this study indicate that the strong influence of political dynasties in Cilegon arises because of the power that has been held since Cilegon City was founded after Banten officially became a province. At that time the elected mayor was Tubagus Aat Syafaat and continued with his sons Tubagus Iman Ariyadi and Ratu Ati Marliati until the 2020 Local Leader Election. The family mainly used the Golkar Party and lower-middle parties to perpetuate their power to form the Minimum Winning Coalition model so that passed the nomination process.
\end{abstract}

Keywords: political dynasty; party coalition; pilkada; cilegon city 


\begin{abstract}
Abstrak
Tulisan ini membahas kekuatan dinasti politik yang ada di Kota Cilegon dalam proses pembentukan koalisi partai politik di Pilkada tahun 2020. Pengejawantahan dinasti politik terus diakomodasi untuk melanggengkan kekuasaan dengan menyampingkan rekam jejak pengalaman pengorganisasian baik di partai maupun di kelembagaan negara. Teori yang digunakan dalam penelitian ini adalah teori dinasti politik dan koalisi partai. Adapun metode penelitian menggunakan kualitatif dengan pendekatan studi kasus eksplanatoris. Fokus kajian ini yaitu mengupas tentang bagaimana peta koalisi terbentuk dan bagaimana pengaruh dinasti terhadap partai-partai politik. Adapun hasil penelitian ini menunjukkan bahwa pengaruh kuat dari dinasti politik di Cilegon muncul akibat dari kekuasaan yang dimiliki sejak Kota Cilegon berdiri setelah Banten resmi menjadi Provinsi. Saat itu yang terpilih sebagai Walikota yaitu Tubagus Aat Syafaat dan dilanjut dengan anaknya Tubagus Iman Ariyadi dan Ratu Ati Marliati sampai pada saat Pilkada 2020. Keluarga tersebut memanfaatkan utamanya Partai Golkar dan partai-partai menengah-bawah untuk melanggengkan kekuasaannya untuk membentuk model Minnimal Winning Coalition agar lolos proses pencalonannya.
\end{abstract}

Kata Kunci: dinasti politik; koalisi partai; pilkada; kota cilegon

\title{
Introduction
}

Democracy is a method used by countries in the world to run the political system in that country. Indonesia is one of the many countries in the world that use a democratic system in carrying out its political system. One of the methods of the democratic system is to conduct elections either directly by the people or through representatives to elect the head of state/head of government from the central level to the regional level. Democracy that was implemented by Indonesia before 2005 in the process of selecting local leader was carried out indirectly. Then in 2005 until now, which is the last of 2020, democracy in the process of selecting regional heads in Indonesia is carried out by means of direct elections. So direct democracy is an important point in maintaining the quality of electability of candidates for local leader. However, it is not without obstacles that direct democracy is implemented, where there are some shortcomings such as deviant political practices.

The direct election in the Local Leader Election (Pilkada) was initially carried out at a time when Indonesia was conducting democratization. Where before 1998, Indonesia was led by the New Order authoritarian regime. However, the process of electing regional heads has become an opening gate and the formation of political dynasties at the local level. One of the most phenomenal political dynasties is the political dynasty of the Tb. Chasan Sochib family with their son, Ratu Atut Chosiah in Banten (Yeby Ma'asan Mayrudin, 
Husna, \& Yuliati, 2020). The Chasan Sochib service has occupied and dominated politics in Banten since the beginning of the Banten Province's establishment by starting with Chasan Sochib's success in sending his daughter to sit in the seat of the Deputy Governor of Banten Province. According to Adnan as the ICW Coordinator (dalam Prastiwi, 2017) said that based on data from the Ministry of Home Affairs (Kemendagri) from 2013 to 2017 there were 58 political dynasties, and the most phenomenal was the political dynasty in Banten, which involved husbands, children, younger siblings, and their families who enter politics in the legislative, executive, and judicial branches.

If we look at Banten in terms of its political map, it cannot be separated from the problem of political dynasties that are so inherent and difficult to remove. Where in several districts and cities in the province of Banten, each of them was occupied by political dynasties apart from the Chasan Sochib clan. The political dynasties include the Ismet Iskandar political dynasty in Tangerang Regency, the Jayabaya political dynasty in Lebak Regency, the Dimyati Natakusumah political dynasty in Pandeglang Regency, and the Aat Syafaat political dynasty in Cilegon City. Studies related to political dynasties in Banten have always been a source of concern for the public in seeing the development of political dynasties themselves, especially during the implementation of the democratic party in the Local Leader Election (Pilkada). As was the case in the simultaneous regional elections in 2020 which were attended by 270 regions and there were 4 regions in the Banten Province that took part in the 2020 elections. These areas include Cilegon City, South Tangerang City, Serang Regency, and Pandeglng Regency. In looking at the pilkada process in Banten, of course, it cannot be separated from the candidacy process which is largely determined by the political dynasties in Banten. The candidacy process that should be the authority of political parties in carrying out the function of party regeneration and appointing the best party cadres to nominate themselves. However, this did not go well, because many parties were oriented towards paragmatism (Yeby Ma'asan Mayrudin, 2017; Yeby Ma'asan Mayrudin, Nurrohman, Utami, \& Hikmawan, 2021) in carrying out the candidacy process, so that political dynasties thrived, especially in Banten.

Political dynasty can be understood as a political strategy to maintain power by passing on the power that has been held to other people who are still relatives. The various symptoms that underlie the formation of a dynasty according to (Djati, 2013) can be analyzed from two things. First, the stalled cadre of political parties in recruiting qualified regional head candidates, thus creating political pragmatism by encouraging relatives of regional heads to become public officials. Second, the context of the community that maintains the status quo condition in their area who wants the local leader to rule by encouraging family members or people close to the local leader to replace the incumbent.

So to see that political dynasties occur and how dynasties can affect the dynamics of the formation of a party coalition to support candidate pairs, we 
try to focus on the dynamics that occurred in the 2020 Cilegon Local Leader Election. Based on the determination of the KPUD of Cilegon City, there are 4 pairs of candidates with each coalition, and 1 candidate pair from the independent path, meaning that it is not promoted by a political party. The candidate pairs and coalitions include the Ratu Ati Marliati-Sokhidin pair supported by the Golkar, Gerindra, Nasdem, and PKB coalitions, then the Heldy Agustian-Sanuji pair promoted by the Berkarya Party and PKS coalition, then there is the Rohiman-Awab carried by the coalition of the Demokrat Party, PAN, and PPP, and the last is the Ali Mujahidin-Firman Mutakin who advanced through the independent path. The formation of the 4 pairs of candidates and the coalition is certainly inseparable from the dynamics and tug-of-war or political lobbies from each political party. However, when viewed from the composition of the four candidates, there is the name Ati Marliati as the incumbent candidate, where Ati is the son of Aat Syafaat and the younger brother of Iman Ariyadi who is a former Mayor of Cilegon. So it is clear that the presence of Ati Marliati as a Candidate for Mayor makes him a label as a political dynasty because Ati comes from a family that previously also served as Mayor of Cilegon.

It is interesting to see political dynasties in the context of the Pilkada of Cilegon City, considering that Ati Marliati is still being nominated even though her brother has been involved in a corruption case. Likewise with the political parties that carry him why are they still convinced to carry Ati Marliati. In addition, if the family of Ati Marliati is in power in Cilegon City, then why can the Ati Marliati dynasty and its party, the Golkar Party, not be able to embrace all political parties to agree to support it. If that option doesn't work, then why does the Golkar Party remain adamant and confident in carrying Ati Marliati as a candidate for Mayor of Cilegon.

The nomination of Ati Marliati by the Golkar Party and other supporting parties is inseparable from the system of regeneration and political recruitment that is not good by political parties. Where political recruitment is not based on quality, but on material or political costs. (Norris, 2006: 95) in his book entitled Political Recruitment says that candidacy is defined as the process of how candidates are selected from potential candidates who can compete for public office. Where in the process will go through three stages, namely certification, nomination, and election, which of the three stages must be carried out by political parties properly.

\section{Theoretical Framework}

\section{Political Dynasty}

According to (Querubin, 2010) political dynasties are defined as the holding of formal political power more than once by one lineage or close relative. A very well-known example is the family of Ratu Atut in Banten. Empirically, political dynasties are not in line with democratic norms because by perpetuating power, it makes a handful of political elites 
themselves control power for generations so that it becomes a milestone in the relay with the spread of networks by wives, children, uncles, and others to be able to occupy positions. strategy in political institutions.

There are three forms of political dynasties, namely the arisan political dynasty model, which means one area is led by one family without a break. Second, political dynasties with a cross-chamber model where this power is branched and divided into strategic positions in an area. Finally, there is a cross-regional model where important positions are controlled by one family with different regional placements. The political culture of familism which makes family ties very dependent, makes it a habit to place family or relatives in a high position. Familism is understood as a new social order where there is a psychological urge to have a career in the public sphere as a bureaucrat and private as a corporate. This political dynasty is related to familism because there is a pure basis of blood relations from family and marital relations. This research is also in line with the concept of familism political dynasties (Garzon, 2002), in which the political realm in Banten is very direct towards the two relationships openly.

\section{Party Coalition}

In a multi-party system, the coalition becomes an inseparable unit because the parties will continue to form the majority vote in every election. The coalition will form a coalition of parties that tend to be stronger than the independent ones. In the KPU regulations, there is a vote requirement or a threshold of $15 \%$ in making nominations. This means that the more coalitions there are, the more votes there will be to meet that limit. The formation of the coalition will be carried out in various ways, namely by looking at the ideological similarities, the common goals, or even just a formality of fulfilling seats without any importance. In theory (Lijphart, 1984) it is divided into two coalition models, namely policy based coalition and policy blind coalition. The two groups are further divided into six category: the Minimal Winning Coalition theory in which a coalition will be formed because of the victory of the majority seat; the second is the Minimum Size Coalition, formed on logical and rational thinking; the third is the Bergaining Proposition which is formed from a mixture of large and small parties; the four theories of Minimal Range Coalition, formed on a common view; the fifth Minimal Connected Winning Coalition where the coalition is formed if it has close relationships; The last is Policy Viable which was formed because of the common concern for policies.

\section{Research Methodology}

The writing in this study uses a qualitative approach with explanatory case studies because basically explanatory will answer and contain in-depth questions such as how and why parties can make quite dynamic shifts (Creswell, 2013). Therefore, researchers will focus more on the explanation of 
case studies and history. The qualitative research method was chosen because it is considered capable of explaining the phenomenon and interpreting the problems studied. Such as by way of description in the form of words and language (Creswell, 2013, 2016) through case studies and through in-depth collection of various kinds of data involving a lot of appropriate information and rich in context that can answer the main problems of this research. The data collection techniques in this study were carried out through observation, interviews, literature studies derived from the results of previous studies, journals, and from existing news portals.

\section{Result and Discussion}

\section{Coalition Formation Process in the 2020 Cilegon Local Leader Election}

Based on the data and sources that the researchers found in the coalition formation process in the 2020 Cilegon Pilkada, there were a lot of changes and shifts that were dynamic enough to carry the candidates. Starting from the emergence of the name Dede Rohana in late 2019, who is considered the most influential young millennial figure, even though he is a member of the Council as well as the Chair of the PAN Faction, he feels called and compelled to advance Cilegon City by noting the potential and various main problems of this city such as unemployment. Then another name emerged from a Banten press figure, Firdaus who also took the form of selecting candidates for Mayor at the PDI-P DPC Secretariat, he had the same vision with PDI-P to make changes and advance Cilegon for the better so that his spirit was adjusted to the platform of the cadres of the party. According to the Cilegon PDI-P screening team, there were only 2 people who took the registration form, Reno Yanuar from internal and Firdaus from external. The party has never differentiated between internal cadres or not, because apart from that they will still prioritize of change agenda.

In early 2020, the KPUD of Cilegon began discussing mechanisms related to the support of candidate pairs including the application of the Nomination Information System (Silon) because there were already 3 pairs of candidates who came from individuals: Ali Mujahidin-Lian Firman, Lukman Harun-Nasir, and Malim Hander Joni-Hawasi Sabrawi. It is not easy for these three pairs of individual candidates to advance in the Pilkada contestation because there are still many requirements that must be completed, such as the minimum requirements for support before proceeding to the verification stage. Other news from a few media, the emergence of the prospective Awab and Iye candidates who could advance in the 2020 Cilegon Pilkada. This is confirmed by the Awab Timses that he has received a Decree (SK) to serve as Chair of the Gerindra DPC Cilegon City, thus will strengthen Awab to run for Pilkada and the Gerindra party itself will carry internal cadres along with other coalitions.

The issues surrounding the 2020 Cilegon Pilkada are still dynamic, as evidenced by the emergence of the names of the new candidate pairs, namely Helldy Agustian as Chair of the DPW Berkarya Banten and Iye Iman Rohiman as PAN cadres. Regarding the interests of the existing coalition, the union of the 
two parties is enough to deliver the prospective pairs of candidates by pocketing 8 seats in the Cilegon City DPRD. On the other hand, the DPW PKS of Banten has also begun to prepare for the names that will run in the contestation. A polling process carried out by the PKS cadres itself which gave rise to 3 names: Norrotul Uyun, Amal Irfanudin, and Qidatul Sitta as the dominant vote but the third this name is still a temporary consideration before being submitted to the DPP PKS.

After many political parties expressed their support for the prospective candidates, now the PPP also provides support in the form of a decree to Iye Iman Rohiman, who previously received a decree from PAN. This information was confirmed by Iye Iman Rohiman that he had received a letter of recommendation from the party $K a^{\prime} b a h$ which was received on February 28, 2020. He said he was positioned as a candidate for mayor with six seats and would continue to build coalitions with other parties.

Furthermore, the Demokrat party did a similar thing, there were two names being discussed for the contestation on Cilegon Pilkada, namely Ratna Soehart as the former Regional Secretary of Banten Province and Helldy Agustian. Reportedly, only these two names participated in the Demokrat forum "Siapa Pantas Jadi Pemimpin, Demokrat Mencari" and have explained their vision and mission so that further surveys will be carried out and become consideration for proposals to the DPP. The DPC of the Cilegon Demokrat Party has opened the registration of candidate pairs for one month starting from November 1 to December 23, 2019, and there are nine names recorded by the selection team from the registration. The names registered are Helldy Agustian from the Berkarya party, Reno Yanuar from PDI-P, Alawi Mahmud, and Dede Rohana from PAN, Ati Marliati from Golkar, Ratna Soeharta from Nasdem, Iye Iman Rohiman and Awab from individuals, and Faturohman Salim as an entrepreneur.

The formation of the coalition is increasingly dynamic and increasingly conical, where there are prospective pairs of candidates who finally officially pair up to take part in the 2020 Cilegon Pilkada for the 2020-2025 period. The couple who seems increasingly convinced that this is from the coalition of the Berkarya and PKS parties with the names Helldy Agustian and Sanuji, both parties have confirmed and carried out an MOU regarding the best cadres of each party, and even campaign posters with the jargon "Cilegon Lebih Baik" and the hashtag "\#koalisipembaharuan" and "\#jiwapembaharu". Even so, they are still open to other parties who want to join and form a coalition. Followed by the pair Ali Mujahidin with Firman Muttaqin who was promoted by an independent channel, the two were still consistent in continuing to pair up and seeking as many votes as possible as a requirement for registration.

Then another pair whose coalition began to appear clear was Ati Marliati with Sokhidin being promoted by the Golkar party, Gerindra party, Nasdem party, PPP party, and PKB party. Finally, the pair Iye Iman Rohiman with Reno Yanuar with the supporting parties namely PDIP, PAN, and Demokrat which 
may be formed if both want to pair up, depending on the party's blessing considering the chances of winning or losing. However, Iye Iman Rohiman was finally paired by the Awab to run for the 2020 Cilegon Pilkada and was carried by the Demokrat party according to a direct decree to the two of them, where Iye Iman Rohiman as a Candidate for Mayor and Awab as a Candidate for Deputy Mayor of Cilegon. This pair of candidates who have started to form also has the opportunity to disband and move in the middle of the road even at the last second of determination because there will be many considerations, both position, cost and logistics of winning.

\section{Shifting Party Coalition Building in the elections in Cilegon}

Coalition formation in the 2020 Cilegon Local Leader Election tends to have an interesting coalition map compared to previous election period. At every moment, of course, the party coalition no longer reflects based on ideological similarities but only prioritizes the victory of power.

If you remember the Cilegon Pilkada in 2005, 2010, and 2015 the coalition of parties that took place was very dynamic, there were many shifts between parties to achieve their interests at certain times. As an example of the Demokrat party, this party in 2005 formed a coalition with the PKS and the PBB, then in 2010 formed a coalition with the PPP, but in 2015 the Demokrat party again collaborated with all three simultaneously to create a fat party with the Nasdem, the Gerindra, and the PDI-P. However, in the last Pilkada, the Demokrat again narrowed down its coalition, which was only collaborating with the PAN and PPP.

On the other hand, it also happened to the Golkar party, the shift in its coalition was also clearly seen in the last Pilkada where the Golkar party formed a coalition with the Gerindra, PKS, and PKB without collaborating with PAN as in the 2005, 2010 and 2015 elections.

Finally, the PDI-P, the party that is always present at every moment of the Cilegon elections, the "Banteng" party is absent in the 2020. PDI-P itself does not enliven this election contestation because it is not included in one of the parties carrying the four existing candidates, the PDI-P. previously wanted to nominate a candidate from within himself and had already issued a decree to be paired with Heldy from the Berkarya party. But in the end Helldy ignored the decree and chose Sanuji from the PKS party to form a coalition with him in the 2020 Cilegon Local Leader Election.

\section{Dynasty Control in Forming Coalition}

The political dynasty in Cilegon is inseparable from the growth of the position held by the figure of Tubagus Aat Syafaat when he was first elected and served as Mayor of Cilegon. Aat served as Mayor for two period, after that his son was also elected as Mayor of Cilegon, namely Tubagus Iman Ariyadi who also served two period. If you look at the year of the founding of Cilegon after Banten Province bloomed or separated from West Java Province, it can be 
said that Aat was the first Mayor to serve by election. Therefore, when the mayor's position was continued to his son who also served for two period, then from there it could be said to be a Political Dynasty.

The political dynasty of Aat Syafaat along with its political vehicle, the Golkar Party, certainly plays an important role in every dynamic of coalition formation that occurs during the process of implementing the regional elections. As has been mentioned in the dynamics of the coalition in the previous discussion. Likewise in the 2020 Cilegon Local Leader Election, the formation of a coalition that occurs is also inseparable from the influence of political dynasties and the Golkar Party, whose position is also to have the most seats in DPRD members among other parties, namely 10 seats or $25 \%$ of seats. The figure of $25 \%$ is of course sufficient for the Party to nominate its own candidate pair, because according to "UU No 10 Tahun 2016" concerning Regional Elections, it is related to the condition that pairs of candidates can carry at least $20 \%$ of the DPRD seats. So based on this regulation, the Cilegon Golkar Party certainly has the opportunity to nominate its own candidate without forming alliances with other parties. However, Golkar prefers to cooperate with other parties, to form a coalition to build a greater power. In the 2020 elections, Golkar is in a coalition with Gerindra, Nasdem, and PKB.

In the 2020 Cilegon Local Leader Election, it is interesting to see the steps and decisions of the Golkar Party in determining and deciding who it will carry. Considering that even though Golkar has always won in previous elections, it is different from the 2020 Pilkada which is faced with various issues. The issues include corruption from the former chairman of the Golkar Party DPC who also served as Mayor of Cilegon in the 2010-2015 and 2016-2021 periods, the issue of political dynasties, and the issue of developments or changes to the development of Cilegon City in the opinion of the people who are considered less successful during their leadership by Aat Intercession's family. So based on these issues, of course, Golkar should be a consideration in determining who it will carry in the 2020 Pilkada. But Golkar still decided to carry the figure of Ratu Ati Marliati who came from a political dynasty to be nominated as a candidate for Mayor of Cilegon. Ati Marliati previously served as Deputy Mayor of Cilegon who was proposed by Golkar after his younger brother Tb. Iman Ariyadi was caught in a corruption case.

In the nomination process, political parties openly give space to every cadre and even non-cadres (non-party or from other parties) to register. However, in practice, most parties, especially the winning parties in the previous Pilkada, often nominate incumbent candidates regardless of bad records or other negative issues. Ikhsan as a Golkar politician in Banten explained that the nominations for the regional head elections usually use the logic of winning and the logic of formal legal requirements. The logic of winning is that the candidate must have a high probability with measuring tools such as surveys. Incumbents are generally considered to already have a track record and are much better known by the public so that it will facilitate 
the winning process. Then each party itself will of course prioritize its cadres in accordance with political goals, namely, to gain power. The logic of fulfilling formal legal requirements such as the two-term limit that must be followed and considered by the party. If the incumbent has been elected for two terms, the party needs to find a replacement figure by considering various things (Fitron Nur Ikhsan, Interview, 2021).

So based on the results of the interview, it can be seen how the attitude and direction of movement chosen by the Golkar Party, where in fact Golkar is the party that became the vehicle for political dynasties in Banten and especially in Cilegon City. So, on the basis of this logic, it is clear that it is the political dynasty that has a great opportunity, because even though the influential figure has been hit by regulations related to a maximum of two periods, this is what ultimately becomes the background for the emergence of other candidates who remain from their families, relatives, or breeds. . For example, when Aa Syafaat, who had been the Mayor of Cilegon for two terms, Aat could no longer nominate, he finally encouraged his son, Iman Ariyadi, as the next Mayor candidate.

As a result, Iman was also successfully elected for two terms, but even though at the end of the period he was caught in a CSR fund corruption case, the Golkar party still believed in his family line which caused Golkar to propose Ati Marliati as Deputy Mayor of Cilegon for the remainder of the 20192021 period. Ati Marliati is the son of Aat Syafaat and the older brother of Iman Ariyadi who are both former Mayors of Cilegon.

So based on this, there is an indication that there is a control from the Aat Syafaat family in determining the candidate to be carried and forming a coalition. This is in line with the view (Querubin, 2010) regarding the political dynasty model, which is included in the arisan model category, which is an area led by one family without a break. This is clearly seen from how the Mayor of Cilegon from period to period is led by Aat Syafaat, Iman Ariyadi, and Ati Marliati, the three of whom are father, son, and brother/brother.

Of course, it was not without reason why the Golkar Party at that time continued to nominate Ati Marliati because of his status as an incumbent candidate who clearly had more provisions than other candidates. However, the coalition formed should be in accordance with the direction of party policies and ideologies that are oriented to the public interest. Where this is also in line with the opinion (Agustino, 2014) which says that the main purpose of political parties is to seek and maintain power to realize planned programs in accordance with certain ideologies or ideologies brought by the party. Where the ideology should be contained in the policy direction of the party coalition that was built at the time of conducting elections both at the central and regional/local levels. It is clear to see the coalition of each candidate and the number of seats in the Cilegon City DPRD from each supporting party, in the following table: 
Table 1

Political Party Coalition in the 2020 Cilegon Local Leader Election

\begin{tabular}{|c|c|c|c|}
\hline $\begin{array}{c}\text { Serial } \\
\text { Number }\end{array}$ & Candidate & Carrier Party & Party Ideology \\
\hline 1 & Ali Mujahidin-Firman Mutakin & Independent & - \\
\hline \multirow{4}{*}{2} & \multirow{4}{*}{ Ratu Ati Marliati-Sokhidin } & Golkar (10 seat) & Nationalist-Secular \\
\hline & & Gerindra (6 seat) & Nationalist-Secular \\
\hline & & Nasdem (3 seat) & Nationalist-Secular \\
\hline & & PKB (1 seat) & Traditional Islam \\
\hline \multirow{3}{*}{3} & \multirow{3}{*}{ Iye Iman Rohiman-Awab } & PAN (4 seat) & Modern Islam \\
\hline & & PPP (2 seat) & Islam \\
\hline & & Demokrat (2 seat) & Nationalist-Religious \\
\hline \multirow{2}{*}{4} & \multirow{2}{*}{ Helldy Agustian-Sanuji } & Berkarya (4 seat) & Nationalist-Secular \\
\hline & & PKS (4 seat) & Islam \\
\hline
\end{tabular}

Source: Processed by Team

So based on the table, it can be seen how the composition of each coalition is filled by parties with their respective ideologies and seat acquisitions. Apart from that, we tried to ask the Banten Democrat Party politician who also serves as the Deputy Chairman of the Banten Provincial DPRD, namely M. Nawa Said Dimyati regarding the party's decision that tends to support the growing Political Dynasty in Banten. He explained that the Democratic Party when it will nominate someone in the Pilkada of course has considerations: first, prioritizing internal cadres; second, looking at the electoral process; third, having the capacity and capability to become a leader; and fourth, having the responsibility to advance Banten. Dimyati said:

"Kalau kemudian kebetulan si A itu anaknya Wapres, orang tuanya mantan Bupati [Walikota] itu sekedar kebetulan aja tapi bukan menjadi dasar untuk menentukan. Lalu di Pandeglang itu kenapa kita dukung Ibu Irna itu karena anak bu Irna salah satu legislatif DPR RI Partai Demokrat, itu menjadi salah satu kepercayaan kami maka Demokrat mendukung bu Irna." "If then it happens that A is the son of the Vice President, his parents are former Regents, it's just a coincidence but not the basis for determining. Then in Pandeglang, why do we support Mrs. Irna because Mrs. Irna's daughter is one of the legislators of the DPR RI, the Demokrat Party, that is one of our beliefs, so we support Mrs. Irna." (Dimyati, Wawancara, 2021).

Based on this answer, it can be seen how the demokrat party's attitude that related to the main priority of the three examples of people promoted by the Demokrat are people who have family ties to a person who is currently holding a position or has served, whether it is vice president or former regent/mayor. Of course, this is clearly a practice of political dynasties, although it is done in a subtle way. 
So based on the answer, the parties seem to have no problem with dynastic politics and view it as a normal thing to do because it is protected by the constitution. However, in our opinion, in political ethics there must be a limit so that a party does not continue to perpetuate the power held by one circle because it has clearly been proven in many regions that regional heads from political dynasties have been entangled in corruption cases. This is of course due to access and networks that make it easy for him to do this, because the opportunity will not be wasted. Therefore, it is the political party that has to set boundaries, even if not formally.

When considering the political behavior of parties and their elites responding to the phenomenon of political dynasty, it can be said that they have no problem with this phenomenon as long as the party has a fairly large chance of winning. Of course, if this continues, the words of pragmatic political parties can be said to be true. As in the Cilegon City Election, how have the Aat Syafaat Dynasty held the title of Mayor for 4 periods and in the fifth period, namely 2020, the Aat Syafaat dynasty also advanced to nominate itself as a Candidate for Mayor of Cilegon from the Golkar Party. Of course, it is very clear that political dynasties have enormous control over the parties in making decisions and the direction of their movements.

\section{Conclusion}

Based on the results of the above discussion, it can be concluded that in a multiparty system, coalitions are unavoidable in the political process itself because the majority vote is one of the main prerequisites for being able to run as a candidate in the Local Leader Election. The dynamics in the coalition are also very dynamic, as can be seen from the history and map of the coalition formed in the nomination process at every election moment. Candidates or pairs of candidates who have been formed temporarily will continue to have the opportunity to make shifts before going to the stage of determining the pair of candidates by the KPU, this is due to the many considerations between parties to expedite the winning process. If we look at the history of the 2020 Pilkada which has just taken place with the previous elections, coalition formation in Cilegon tends to prioritize the interests of victory over ideological similarities. This is evidenced by the existence of a political dynasty in Cilegon, the emergence of strong people from Local Leader Election products will create important posts for their families so that they can occupy political positions. It is also justified by a few political parties by referring to the two prevailing logics, namely the logic of winning and the logic of requirements where relatives or incumbent candidates are indeed a fast path for political parties to nominate candidates, because track records and popularity will facilitate the process of winning which is the main goal. Defense is likened to a brand or brand in politics that runs a dynastic system. Although the defense does not guarantee victory, the percentage of the defense's victory will be much greater and dominant than the loser. 
Thus, when analyzed with Lijphart's coalition theory, the shift and coalition formation that occurred in the 2020 Cilegon Local Leader Election refers to the Minnimal Winning Coalition model where parties will form coalitions based on winning the majority of seats only so that the composition of each coalition is adjusted to the results obtained. their respective seats. The political dynasty in Cilegon City also shows a model of the social gathering political dynasty where in the 4 Cilegon Local Leader Election periods, namely $2005,2010,2015$, and 2020, they continue to try to maintain power without a break in one family. The predicate of the Aat Syafaat dynasty proves that the dynasty has control over a very large party to determine its direction and decisions.

\section{About Authors}

Abdul Riyansah is a student in the Department of Government Science, Faculty of Social and Political Sciences, University of Sultan Ageng Tirtayasa (UNTIRTA). He is interested in the study of Elections and the Party System.

Ferliana is a student in the Department of Government Science, Faculty of Social and Political Sciences, University of Sultan Ageng Tirtayasa.

Yeby Ma'asan Mayrudin is a Lecturer in the Department of Government Science, Faculty of Social and Political Sciences, University of Sultan Ageng Tirtayasa.

Moh. Rizky Godjali is a Lecturer in the Department of Government Science, Faculty of Social and Political Sciences, University of Sultan Ageng Tirtayasa.

\section{Acknowledgements}

We express our deepest gratitude to Allah SWT for all the abundance of blessings that have been given so that this research can be completed. In addition, we would like to thank the informants in this study, namely the Golkar Party, the PDI-P, and the Demokrat Party who were willing to be interviewed. Then we also thank all parties who have helped in this research such as the Study Program, Faculty, and LPPM Untirta.

\section{References}

Agustino, L. (2014). Pengantar Ilmu Politik. Serang: Untirta Press.

Creswell, J. W. (2013). Qualitative Inquiry E Research Design: Choosing Among Five Approaches (Third Edit). California: SAGE Publication.

Creswell, J. W. (2016). Reaserch Design, pendekaan metode kualitatif, kuantitatif, dan campuran (4th ed.). yogyakarta: PUSTAKA PELAJAR.

Dimyati, M. N. S. (2021). “Kendali Dinasti terhadap Partai Politik di Banten." Banten.

Djati, W. R. (2013). Revivalisme Kekuatan Familisme dalam Demokrasi: Dinasti 
Politik di Aras Lokal. Jurnal Sosiologi, 18(2).

Garzon, A. (2002). Familism. New York: MacMillan.

Ikhsan, F. N. (2021). “Kendali Dinasti Politik di Pilkada Kota Cilegon 2020." Banten.

Lijphart, A. (1984). Democracies: Patterns of Majoritarian and Consensus

Government in Twenty-One Countries. Naw Haven: Yale University Press.

Mayrudin, Yeby Ma'asan. (2017). Dinamika Partai Politik Dan Positioning Ideologi: Studi Tentang Pergeseran Positioning Ideologi Partai-Partai Politik Peserta Pemilu 2014. Journal of Governance, 2(2), 163-185. https://doi.org/10.31506/jog.v2i2.2674

Mayrudin, Yeby Ma'asan, Husna, N. A., \& Yuliati, F. R. (2020). Kontestasi Kuasa Kepemimpinan Formal dengan Informal dalam Kebijakan Publik dan Politik Keseharian. Journal of Political Issues, 2(1), 1-9. https://doi.org/10.33019/jpi.v2i1.30

Mayrudin, Yeby Ma'asan, Nurrohman, B., Utami, W. K., \& Hikmawan, M. D. (2021). Discursive Political Environment in Indonesian Political Parties: A Study on Partai Kebangkitan Bangsa (PKB). E3S Web of Conferences, 277, 01004. https://doi.org/10.1051/e3sconf/202127701004

Norris, P. (2006). Political Recruitment. London: Sage Publication.

Prastiwi, D. (2017). ICW: Ada 58 Dinasti Politik di Indonesia.

Querubin. (2010). Family and Politics: Dynastic persistence in the Philippines. MIT: Unpublished Manuscript. 